\title{
Tailoring the crystal structure of $\mathrm{CaTiO}_{3}$ by multielement doping for photo-assisted activation of NO
}

\section{Yilong Ji}

Anhui University of Technology

\section{Bo Ding}

Anhui University of Technology

\section{Wen Ni}

Anhui University of Technology

\section{Xiazhang Li}

Changzhou University https://orcid.org/0000-0002-2528-4121

\section{Xiaojun He}

Anhui University of Technology

\section{Zhiyuan Chen}

Flemish Institute for Technological Research

\section{Songlin Ran}

Anhui University of Technology

Hui-Hong LÜ ( $\square$ lv_huihong@163.com )

Anhui University of Technology

\section{Article}

Keywords: photocatalysis, perovskite, selective catalytic reduction, element doping, NO activation

Posted Date: February 24th, 2022

DOI: https://doi.org/10.21203/rs.3.rs-1286081/v1

License: (c) (1) This work is licensed under a Creative Commons Attribution 4.0 International License.

Read Full License 


\section{Abstract}

Although photocatalysis exhibits great prospects in selective catalytic reduction of $\mathrm{NO}_{x}$ (photo-SCR), the principles toward informed design of photo-SCR catalysts are lacking. Herein, based on inert $\mathrm{CaTiO}_{3}$, we tailor a crystal structure for high-efficiency deNO $\mathrm{N}_{\mathrm{x}}$ by partially substituting $\mathrm{Ca}$ with $\mathrm{Ce}$, and $\mathrm{Ti}$ with $\mathrm{Fe}$ and $\mathrm{Mn}$. The pristine $\mathrm{CaTiO}_{3}$ is hard to remove $\mathrm{NO}$ in $100-300^{\circ} \mathrm{C}$, while Ce-Fe-Mn doped $\mathrm{CaTiO}_{3}$ could achieve nearly $100 \%$ NO conversion at $135^{\circ} \mathrm{C}$ under light irradiation (GHSV $=72000 \mathrm{~h}^{-1}$ ). The dopants enable $\mathrm{CaTiO}_{3}$ to activate $\mathrm{NO}$ and harvest visible light. By selectively activating gaseous molecules, $\mathrm{Ti}, \mathrm{Fe}$, and $\mathrm{Mn}$ present significant synergistic effects on accelerating the catalytic cycle of standard SCR. Moreover, it is firmly shown that the photocarriers intensify $\mathrm{NO}$ oxidation rather than $\mathrm{NH}_{3}$-to- $\mathrm{NH}_{2}$ transformation. This work provides new insights into the structure-activity relationship of perovskite-based catalysts, and deepens the understanding of the light-driven mechanism.

\section{Full Text}

Cost-effective construction of $\mathrm{NH}_{3}$-SCR catalytic systems to realize $\mathrm{NO}_{\mathrm{x}}$ removal in the low-temperature range has become urgent given the increasingly stringent environmental requirements. Since Tanaka group $^{1,2}$ sparked the interest in photo-assisted selective catalytic reduction of NO (photo-SCR), a wealth of seminal studies ${ }^{3-6}$ have proved that photoirradiation is pretty efficacious in ameliorating NO conversion and $\mathrm{N}_{2}$ selectivity in the low-temperature range. Although great achievements have been made in this field, to date, we still lack enough recognition of principles for constructing photo-SCR catalysts.

There are three fundamental issues that plague us. The first is that the reaction mechanism of $\mathrm{NH}_{3}-\mathrm{SCR}$ is disputed. $\mathrm{NH}_{2} \mathrm{NO}$ and $\mathrm{NH}_{4} \mathrm{NO}_{2}$ are the two principal intermediates of standard $\mathrm{SCR}$, which form following the Eley-Rideal (E-R) and Langmuir-Hinshelwood (L-H) mechanisms, respectively. The main point of contention is whether the catalytic cycle entails the involvement of $\mathrm{NH}_{4} \mathrm{NO}_{2}{ }^{7-11}$ Some researchers ${ }^{10,12}$ proposed that whether $\mathrm{NH}_{4} \mathrm{NO}_{2}$ prevails depends on the catalyst nature and reaction temperature. Inexplicably, even for catalysts of the same ingredients, different reaction pathways have been reported. ${ }^{10,13}$ The inherent complexity of $\mathrm{NH}_{3}$-SCR reaction mechanism makes the informed construction of catalyst difficult.

The second issue is that the functions of photocarriers on the catalytic redox are unclear. ${ }^{5,14}$ The mainstream view ${ }^{15,16}$ believed that light irradiation facilitates the transformation of chemisorbed $\mathrm{NH}_{3}$ to $\mathrm{NH}_{2}$ radical, thus accelerating the formation of the unstable intermediate $\mathrm{NH}_{2} \mathrm{NO}$ proceeding via Eley-Ride kinetics. Recently, by illuminated in situ DRIFTS, Gang et al. ${ }^{17}$ found that photoirradiation could drive the oxdiation of $\mathrm{NO}$ into nitrite and nitrate over Fe-doped $\mathrm{TiO}_{2}$. However, two questions remain to be answered : (i) is this promotional effect applicable to other types of photocatalysts, such as perovskites? 
(ii) could the photocarriers transform the chemisorbed $\mathrm{NH}_{3}$ to $\mathrm{NH}_{2}$ species? Therefore, this fundamental issue about the light-driven effect has not been systematically conclusive.

The last is the elusive correlation between surface activity and optical property, both of which are intrinsically determined by the electronic structure of the catalyst. For perovskite oxides of the $\mathrm{ABO}_{3}$ formula, the electron occupancy in $e_{g}$ orbitals of the B-site element has been demonstrated as a useful descriptor to approximate the strength of adsorbate binding to the surface. ${ }^{18}$ Modifying the crystal structure also impacts the optical property, along with the quantum efficiency. ${ }^{19,20}$ The major challenge of photocatalyst design lies in how to tailor the crystal structure to harmonize the molecule adsorption and light response.

The perovskite structure is flexibly tunable since both $A$ and $B$ sites are easily doped by other elements. ${ }^{21,22}$ Previously, our group ${ }^{16,23}$ reported that perovskite-based catalysts have excellent photoactivity for NO removal, and doping perovskite with transition metal ions could evidently improve its performance. In this work, we choose the inert $\mathrm{CaTiO}_{3}$ as a basal material and construct an efficient structure for photo-SCR deNO $\mathrm{N}_{\mathrm{x}}$ by doping it with $\mathrm{Ce}, \mathrm{Fe}$, and $\mathrm{Mn}$ elements. From $\mathrm{Mn}$ doping to $\mathrm{Ce}-\mathrm{Fe}-\mathrm{Mn}$ doping, each step modifies the crystal structure of $\mathrm{CaTiO}_{3}$, making it increasingly elaborate and efficient. By combining experiments with DFT calculations, a systematic investigation into the relationships between intrinsic activity and crystal structure is implemented, as well as the light-driven mechanism.

\section{Results}

Synthesis and catalyst characterization. All the perovskite samples are extracted from Ti-bearing blast furnace slag (Ti-slag) using a molten salt method followed by acid leaching. The chemical compositions of Ti-slag are placed in supplementary Table 1. By roasting Ti-slag with $\mathrm{NaOH}$ at $1400^{\circ} \mathrm{C}$, a molten system consisting of $\mathrm{Na}_{2} \mathrm{O}-\mathrm{CaO}-\mathrm{MgO}-\mathrm{TiO}_{2}-\mathrm{Al}_{2} \mathrm{O}_{3}-\mathrm{SiO}_{2}$ was acquired. With the decrease in temperature, $\mathrm{CaTiO}_{3}$ crystallized from the molten salt, and the rest formed a zeolite phase (supplementary Fig. 1). Three metal oxides, including $\mathrm{CeO}_{2}, \mathrm{Fe}_{2} \mathrm{O}_{3}$, and $\mathrm{MnO}_{2}$, are also added into the mixture to modify $\mathrm{CaTiO}_{3}$. EDS mapping analysis on the roasted slag in Fig. 1a illustrates that most of $\mathrm{Ca}, \mathrm{Ti}, \mathrm{Ce}$, and $\mathrm{Mn}$ are preferentially concentrated into the perovskite, while $\mathrm{Na}, \mathrm{Mg}, \mathrm{Al}$, and $\mathrm{Si}$ are enriched in the zeolite. The distribution of Fe shows little difference between perovskite and zeolite, perhaps due to its considerable solubility in both two phases. The zeolite is easily removed by acid leaching, and thus high-purity perovskite samples are obtained.

The perovskite obtained by introducing $10 \mathrm{wt} \% \mathrm{CeO}_{2}$ is designated as $10 \mathrm{Ce}$, and so on. The chemical compositions of the resultant samples are listed in supplementary Table 2. All the adscititious metal oxides are well incorporated into the samples, such as $19.7 \mathrm{wt} \% \mathrm{CeO}_{2}$ of $10 \mathrm{Ce}, 12.0 \mathrm{wt} \% \mathrm{Fe}_{2} \mathrm{O}_{3}$ of $10 \mathrm{Fe}$, and $10.4 \mathrm{wt} \% \mathrm{MnO}$ of $10 \mathrm{Mn}$. XRD analysis in Fig. 1b demonstrates that each sample is comprised of a perovskite phase. The (112) peaks from both $10 \mathrm{Ce}$ and $10 \mathrm{Fe}$ shift to the left relative to pure $\mathrm{CaTiO}_{3}$, 
showing that either Ce or Fe doping enlarges the unit cell. Conversely, Mn doping (10Mn) causes a right shift of (112) peak, lessening the lattice.

The morphology of the 5 Ce5Fe10Mn specimen is investigated by HAADF-STEM and displayed in supplementary Fig. 2. In general, the particles from $5 \mathrm{Ce} 5 \mathrm{Fe} 10 \mathrm{Mn}$ are irregular and vary from dozens to several hundred nanometers. Elemental mapping on a typical particle (Fig. 1c) revealed that $\mathrm{Ca}, \mathrm{Ti}, \mathrm{Fe}, \mathrm{Ce}$, and $\mathrm{Mn}$ uniformly disperse in the particle at the nanometer scale. Hence, the dopants of $\mathrm{Ce}, \mathrm{Fe}$, and $\mathrm{Mn}$ are incorporated into the $\mathrm{CaTiO}_{3}$, forming a homogeneous solid solution rather than a mixture of metal oxides.

EXAFS spectra of $5 \mathrm{Ce} 5 \mathrm{Fe} 10 \mathrm{Mn}$ and $10 \mathrm{Ce}$ samples are recorded to reveal the positions of dopants in perovskite (Fig. 2). The Fourier-transformed k-space EXAFS spectra are displayed in supplementary Fig. 3, and the fitting parameters are placed in supplementary Table 3-5. The fitted coordination number of the Fe atom in $5 \mathrm{Ce} 5 \mathrm{Fe} 10 \mathrm{Mn}$ is 6.0 . The coordination number of the $\mathrm{Mn}$ atom is constrained as 6.0 in the fitting for Mn K-edge EXAFS spectra, and the $\mathrm{R}$ factor is returned as $1.5 \%$. These results confirmed that both $\mathrm{Fe}$ and $\mathrm{Mn}$ substitute $\mathrm{Ti}$ in $\mathrm{CaTiO}_{3}$ and occupy the $\mathrm{B}$ sites. Constraining the coordination number of Ce atom as 12.0 returns $0.5 \%$ of $R$ factor, substantiating that Ce substitutes $C a$ and occupies the $A$ site. $A$ diagram is presented in Fig. $2 \mathrm{~d}$ to illustrate the crystal structure of Ce-Fe-Mn doped $\mathrm{CaTiO}_{3}$.

The specific surface areas of the samples are in a range of $14.9-16.5 \mathrm{~m}^{2} / \mathrm{g}$ (supplementary Table 6), and the pore volumes are in $0.022-0.033 \mathrm{~cm}^{3} / \mathrm{g}$. The two parameters are almost one magnitude less than the nanocomposites fabricated by homogeneous precipitation ${ }^{24}$, probably due to the fact that the samples are prepared by a high-temperature process.

$\mathrm{NH}_{3}$-SCR activity of singleelement doped $\mathrm{CaTiO}{ }_{3}$. The pure $\mathrm{CaTiO}_{3}$ is hard to remove $\mathrm{NO}_{x}$ in $100-300^{\circ} \mathrm{C}$ (Fig. 3a). After introducing $\mathrm{Ce}$, $\mathrm{Fe}$, or $\mathrm{Mn}$, the modified $\mathrm{CaTiO}_{3}$ becomes active, showing that both $\mathrm{A}$ and $\mathrm{B}$ sites are responsible for the catalytic activity of perovskite. In terms of identical doping amount in mass ratio, $5 \mathrm{Mn}$ is superior to $5 \mathrm{Ce}$ and $5 \mathrm{Fe}$. In particular, $10 \mathrm{Mn}$ could achieve $97.7 \% \mathrm{NO}_{\mathrm{x}}$ conversion at $250^{\circ} \mathrm{C}$, exhibiting outstanding advantage of $\mathrm{Mn}$ doping to gift $\mathrm{CaTiO}_{3}$ activity for $\mathrm{NH}_{3}-\mathrm{SCR}$ deNO $\mathrm{x}_{\mathrm{x}}$.

In situ DRIFTS spectra of adsorbing $\mathrm{NO}+\mathrm{O}_{2}$ over $\mathrm{CaTiO}_{3}$ and $10 \mathrm{Mn}$ were given in Fig. 3b. Three strong bands peaking at $1565 \mathrm{~cm}^{-1}, 1423 \mathrm{~cm}^{-1}$, and $1343 \mathrm{~cm}^{-1}$ from $10 \mathrm{Mn}$ are assigned to bidentate nitrate, nitro compounds, and bridged nitrites, respectively. However, all the three bands from $\mathrm{CaTiO}_{3}$ are quite weak, indicating that pure $\mathrm{CaTiO}_{3}$ is difficult to activate gaseous $\mathrm{NO}$ molecule.

DFT calculations were performed to further investigate the effect of $\mathrm{Mn}$ doping on $\mathrm{CaTiO}_{3}$ activity. The (001)-plane termination exposing $\mathrm{TiO}_{2}$ atoms is chosen as a basal surface of $\mathrm{CaTiO}_{3}$, which is relatively stable under the anoxic condition. ${ }^{25,26}$ As shown in Fig. $3 c$, pure $\mathrm{CaTiO}_{3}$ is capable of adsorbing $\mathrm{NH}_{3}$ on the five-coordinated $\left(\mathrm{Ti}_{5 \mathrm{c}}\right)$ site with an adsorption energy of $-0.86 \mathrm{eV}$, but hard to capture $\mathrm{NO}$ as the adsorption energy is $-0.19 \mathrm{eV}$ (Fig. 3d). With the introduction of $\mathrm{Mn}$ into $\mathrm{CaTiO}_{3}$ (supplementary Fig. 4), 
the adsorption energy of $\mathrm{NH}_{3}$ slightly increases to $-1.09 \mathrm{eV}$ (Fig. 3e). Intriguingly, $\mathrm{NO}$ could bond strongly to the $\mathrm{Mn}_{5 \mathrm{c}}$ site of $\mathrm{Ca}(\mathrm{Ti}, \mathrm{Mn}) \mathrm{O}_{3}\left(\mathrm{E}_{\mathrm{ads}}=-1.37 \mathrm{eV}\right)$ as a bidentate anion carrying 0.20 electrons according to Bader charge analysis (Fig. 3f).

The adsorption configuration of $\mathrm{NO}$ on $\mathrm{MnO}_{5}$ pyramids well satisfies the requirement of spatially symmetric overlap between $\mathrm{NO} \pi^{*}$ orbitals and $\mathrm{MnO}_{5} \mathrm{e}_{\mathrm{g}}$ orbitals. ${ }^{27}$ The redundant electrons in $\mathrm{NO}$ anion prefer occupying the antibonding orbital $2 \pi$ of $\mathrm{NO}$, weakening the $\mathrm{N}-\mathrm{O}$ bond so that the chemisorbed $\mathrm{NO}$ is vulnerable to the lattice or chemisorbed oxygens to generate $\mathrm{NO}_{2}$ (fast SCR) ${ }^{28-32}$, or the chemisorbed $\mathrm{NH}_{3}$ on adjacent $\mathrm{Ti}_{5 \mathrm{c}}$ to yield intermediate $\mathrm{NH}_{2} \mathrm{NO}$ (L-H pathway). As depicted in supplementary Fig. 5 , the formation of $\mathrm{NH}_{2} \mathrm{NO}$ on the surface of $\mathrm{Mn}$-doped $\mathrm{CaTiO}_{3}$ is energetically favorable. Therefore, the SCR activity of $\mathrm{Ca}(\mathrm{Ti}, \mathrm{Mn}) \mathrm{O}_{3}$ derives from the activation of $\mathrm{NO}$ by the $\mathrm{Mn}_{5 \mathrm{c}}$ site.

$\mathrm{NH}_{3}$-SCR activity of multielement doped $\mathrm{CaTiO}_{3}$. Compared with $10 \mathrm{Mn}$, the activity of $5 \mathrm{Fe} 10 \mathrm{Mn}$ is significantly improved in $100-300^{\circ} \mathrm{C}$ (Fig. 4a). The $\mathrm{NO}_{\mathrm{x}}$ conversion over $5 \mathrm{Fe} 10 \mathrm{Mn}$ reached $99 \%$ at $175^{\circ} \mathrm{C}$, far more than the sum of these over sole $5 \mathrm{Fe}$ and $10 \mathrm{Mn}$ (Fig. 3a). Fe-Mn doping of $\mathrm{CaTiO}_{3}$ presents synergistic effects on removing $\mathrm{NO}_{\mathrm{x}}$. Nevertheless, if we continued doping $5 \mathrm{Fe} 10 \mathrm{Mn}$ with $5 \mathrm{wt} \% \mathrm{CeO}_{2}$, the performance showed little difference between $5 \mathrm{Ce} 5 \mathrm{Fe} 10 \mathrm{Mn}$ and $5 \mathrm{Fe} 10 \mathrm{Mn}$ in $100-300^{\circ} \mathrm{C}$ (Fig. $4 \mathrm{a}$ ).

XPS analysis in Fig. 4b showed that with the incorporation of Fe into $10 \mathrm{Mn}$, the peak assigned to $01 \mathrm{~s}$ shifts from $529.0 \mathrm{eV}$ to the higher energy of $529.3 \mathrm{eV}$, indicating that the surface oxygens from $10 \mathrm{Mn}$ carried more electrons than those from $5 \mathrm{Fe} 10 \mathrm{Mn}$. It is easy to understand that the substitution of B-site $\mathrm{Ti}^{4+}$ by aliovalent $\mathrm{Fe}^{3+}$ leads to the decrease in the valence electrons transferring to the oxygen anions (Charge distribution of lattice oxygen is placed in supplementary Fig. 6).

The redox behaviors of $10 \mathrm{Mn}$ and $5 \mathrm{Fe} 10 \mathrm{Mn}$ were also evaluated by $\mathrm{H}_{2}$-TPR experiments (supplementary Fig. 7). The strongest peak from $10 \mathrm{Mn}$ is centered at $604.4^{\circ} \mathrm{C}$, and that from $5 \mathrm{Fe} 10 \mathrm{Mn}$ at $566.3^{\circ} \mathrm{C}$. Fe addition shifts the reduction peak to the lower temperature, enhancing the diffusion of $\mathrm{O}^{2-}$ anion within the lattice. ${ }^{33}$ This might be partially ascribed to the oxygen vacancies introduced by the $p$-type doping of perovskite, which facilitates the movements of electrons and oxygen ions. ${ }^{34}$ The oxygen vacancies also provide energetically favorable connection channels for gaseous $\mathrm{O}_{2}$ molecules, triggering the dissociation of $\mathrm{O}_{2}$ into $\mathrm{O}$ atoms, further expediting the oxidation of $\mathrm{NO} .{ }^{35}$ However, considering that the $5 \mathrm{Fe}$ sample as a p-type doped perovskite possesses similar features, the synergetic effects between Fe and Mn dopants could not be ascribed to the oxygen vacancies.

To explore the underlying mechanism, we built a $\mathrm{CaTiO}_{3}$ model with $\mathrm{Fe}$ and $\mathrm{Mn}$ atoms situated in the $\mathrm{B}$ sites (supplementary Fig. 6c). In this model, the $\mathrm{FeO}_{6}$ and $\mathrm{MnO}_{6}$ octahedra are conjoined with each other by a bridged oxygen. DTF calculations reveal that for $\mathrm{Mn}$-doped $\mathrm{CaTiO}_{3}$, the gaseous $\mathrm{O}_{2}$ molecule prefers binding to the $\mathrm{Mn}_{5 \mathrm{c}}$ and $\mathrm{Ti}_{5 \mathrm{c}}$ sites with an adsorption energy of $-1.26 \mathrm{eV}$ (Fig. 4c). The chemisorbed $\mathrm{O}_{2}$ could further combine with gaseous $\mathrm{NO}$ to produce monodentate nitrate binding to the $\mathrm{Mn}_{5 \mathrm{c}}$ site $(\Delta \mathrm{E}=$ 
$-1.65 \mathrm{eV}$ ) as shown in Fig. 4d (supplementary Video 1). By contrast, for Fe-Mn doped $\mathrm{CaTiO}_{3}$, the gaseous $\mathrm{O}_{2}$ molecule selectively binds to the $\mathrm{Fe}_{5 \mathrm{c}}$ site rather than the $\mathrm{Mn}_{5 \mathrm{c}}$ or $\mathrm{Ti}_{5 \mathrm{c}}$ site (Fig. $4 \mathrm{e}, \mathrm{E}_{\mathrm{ads}}=-1.12 \mathrm{eV}$ ).

The subsequently generated nitrate is still attached to the $\mathrm{Fe}_{5 \mathrm{c}}$ site (Fig. $4 \mathrm{f}, \mathrm{E}_{\mathrm{ads}}=-2.56 \mathrm{eV}$, supplementary Video 2). The addition of Fe into Mn-doped $\mathrm{CaTiO}_{3}$ converts the oxidation center of $\mathrm{NO}$ to nitrate from the $\mathrm{Mn}_{5 \mathrm{c}}$ site to the $\mathrm{Fe}_{5 \mathrm{c}}$ site. This conversion exerts profound influence on the reaction pathway of the SCR process since nitrate is the precursor of $\mathrm{NH}_{4} \mathrm{NO}_{2}$.

Based on DFT calculations, we propose two reaction routes to describe the standard SCR over Mn and Fe$\mathrm{Mn}$ doped $\mathrm{CaTiO}_{3}$. As shown in Fig. 5 , the catalytic cycle over $\mathrm{Ca}(\mathrm{Ti}, \mathrm{Mn}) \mathrm{O}_{3}$ (the outer ring) comprises thirteen steps involving the $\mathrm{NH}_{2} \mathrm{NO}$ and $\mathrm{NH}_{4} \mathrm{NO}_{2}$ intermediates. ${ }^{9,11,13}$ In this cycle, both two intermediates bind to the $\mathrm{Mn}_{5 \mathrm{c}}$ site thus their formations have to proceed by sequence. Fe-Mn doping makes $\mathrm{O}_{2}$ selectively bind to the $\mathrm{Fe}_{5 \mathrm{c}}$ site, lightening the burden of the $\mathrm{Mn}_{5 \mathrm{c}}$ site, and also increasing the $\mathrm{NO}$ coverage on $\mathrm{Mn}_{5 \mathrm{c}}$ sites. More importantly, $\mathrm{NH}_{4} \mathrm{NO}_{2}$ could form in tandem with the generation of $\mathrm{NH}_{2} \mathrm{NO}$, markedly shortening the reaction pathway. The catalytic cycle over $\mathrm{Ca}(\mathrm{Ti}, \mathrm{Mn}, \mathrm{Fe}) \mathrm{O}_{3}$ could be completed within eight steps (the inner ring in Fig. 5).

Photo-SCR activity of doped $\mathrm{CaTiO}_{3}$. Under light irradiation, the performance of perovskite for NO removal is significantly improved, especially in $100-200{ }^{\circ} \mathrm{C}$ (Fig. 6a). The $99 \%$-conversion temperature over illuminated $5 \mathrm{Ce} 5 \mathrm{Fe} 10 \mathrm{Mn}$ is about $135^{\circ} \mathrm{C}$, far lower than $175^{\circ} \mathrm{C}$ over ground-state $5 \mathrm{Ce} 5 \mathrm{Fe} 10 \mathrm{Mn}$ (Fig. 4a). As the light turns on at $125^{\circ} \mathrm{C}$ (Fig. 6b), $\mathrm{NO}_{\mathrm{x}}$ conversion over $5 \mathrm{Ce} 5 \mathrm{Fe} 10 \mathrm{Mn}$ rises from about $56-$ $71 \%$ at $125^{\circ} \mathrm{C}$ without the decrease in $\mathrm{N}_{2}$ selectivity, demonstrating that photocatalysis could serve as a green and effective technique to promote NO removal.

Pristine $\mathrm{CaTiO}_{3}$ is hard to harvest the visible light due to its wide bandgap of $3.2 \mathrm{eV}$. By introducing dopants, the light wavelength absorbed by perovskite extends from the ultraviolet band to the visible band (Fig. 6c). The calculations on the projected density of states (Fig. 6d) disclose that Mn doping introduces an impurity band composed of $\mathrm{Mn} 3 \mathrm{~d}$ and $\mathrm{O} 2 \mathrm{p}$ orbitals between the valance and conduction band. For Fe-Mn doped $\mathrm{CaTiO}_{3}$, there are four impurity bands, including the donor levels composed of $\mathrm{Fe}$ $3 d, M n 3 d$, and $02 p$ orbitals below Fermi level, and the acceptor levels composed of $\mathrm{Mn} 3 \mathrm{~d}$ and $02 \mathrm{p}$ orbitals above Fermi level. The impurity levels narrow the bandgap and enable the perovskite to harvest the visible light.

Although $5 \mathrm{Ce} 5 \mathrm{Fe} 10 \mathrm{Mn}$ shows little difference in NO removal with 5Fe10Mn in the dark (Fig. 4a), the former is notably superior to the latter under light irradiation (Fig. 6a). Li et al. ${ }^{5}$ previously reported that $\mathrm{PrFeO}_{3}$ doped with $\mathrm{Ce}$ displays a redshift of UV-vis absorption. Similar phenomena are observed in Fig. 6c. Relative to $5 \mathrm{Fe} 10 \mathrm{Mn}, 5 \mathrm{Ce} 5 \mathrm{Fe} 10 \mathrm{Mn}$ exhibits enhanced light adsorption in the wavelength range from $500 \mathrm{~nm}$ to $800 \mathrm{~nm}$. The optimization of optical property by Ce doping improves the perovskite photoactivity. 
To unravel photocarriers roles in NO removal, in situ IR spectra of $5 \mathrm{Ce} 5 \mathrm{Fe} 10 \mathrm{Mn}$ with gaseous molecules adsorbed were recorded in the dark and light at $125^{\circ} \mathrm{C}$. The dark spectra of $\mathrm{NH}_{3}$-adsorbed $5 \mathrm{Ce} 5 \mathrm{Fe} 10 \mathrm{Mn}$ (black line in Fig. 6e) have four strong peaks. Two peaks around $931 \mathrm{~cm}^{-1}$ and $966 \mathrm{~cm}^{-1}$ are assigned to weakly absorbed $\mathrm{NH}_{3},{ }^{36}$ the one centered at $1250 \mathrm{~cm}^{-1}$ corresponds to $\mathrm{NH}_{3}$ coordinated on Lewis acid site, ${ }^{37}$ and that around $1366 \mathrm{~cm}^{-1}$ belongs to $\mathrm{NH}_{4}{ }^{+}$bonded to Bronsted acid site. ${ }^{38}$ The illuminated spectra (red line in Fig. 6e) vary little in comparison to the dark counterpart. Most peaks remain unchanged except for those at $1250 \mathrm{~cm}^{-1}$ and $1366 \mathrm{~cm}^{-1}$. The intensity of the former increases while the latter becomes a bit weak, suggesting that under light irradiation, the adsorption of $\mathrm{NH}_{3}$ on the Lewis acid site is enhanced while the adsorption on the Bronsted acid site is mildly inhibited.

The characteristic absorption peaks of $\mathrm{NH}_{2}$ species are generally distributed in the range of 1505-1580 $\mathrm{cm}^{-1} .{ }^{39}$ Nevertheless, none of such peaks appears in the dark or illuminated spectra, clearly substantiating that the $\mathrm{N}-\mathrm{H}$ bond from the chemisorbed $\mathrm{NH}_{3}$ on $5 \mathrm{Ce} 5 \mathrm{Fe} 10 \mathrm{Mn}$ is hard to break at $125^{\circ} \mathrm{C}$, even assisted by light irradiation.

There are four strong peaks in the dark spectra of $5 \mathrm{Ce} 5 \mathrm{Fe} 10 \mathrm{Mn}$ with $\mathrm{NO}+\mathrm{O}_{2}$ adsorbed (black line in Fig. 6f). These located at $1600 \mathrm{~cm}^{-1}$ and $1630 \mathrm{~cm}^{-1}$ are assigned to the bridged nitrate, ${ }^{17}$ and those at $1850 \mathrm{~cm}^{-1}$ and $1960 \mathrm{~cm}^{-1}$ are ascribed to the weakly adsorbed NO species. The illuminated spectra (red line in Fig. 6f) show apparent differences from the dark counterpart. On the one hand, the intensities of the above four peaks become stronger. On the other, a series of strong peaks appear in the range from $1495 \mathrm{~cm}^{-1}$ to $977 \mathrm{~cm}^{-1}$. The peak at $1100 \mathrm{~cm}^{-1}$ is assigned to nitrito monodentate species, ${ }^{40}$ those around $1200 \mathrm{~cm}^{-1}, 1332 \mathrm{~cm}^{-1}$, and $1465 \mathrm{~cm}^{-1}$ are attributed to nitrites, ${ }^{33,41}$ and that at $1495 \mathrm{~cm}^{-1}$ corresponds to monodentate nitrate. ${ }^{36}$ These results manifest that light irradiation dramatically promotes $\mathrm{NO}$ oxidation rather than $\mathrm{NH}_{3}$-to- $\mathrm{NH}_{2}$ transformation.

\section{Discussion}

The conventional fabrication of Ti-based perovskite always uses expensive tetrabutyl titanate as a precursor. ${ }^{42}$ Nowadays, titanium extraction from minerals still needs to go through complicated procedures with high costs. In this work, $\mathrm{CaTiO}_{3}$ is synthesized by a molten-salt method with sodium aluminosilicate as the flux. This method provides a possibility to directly extract high-purity Ti-based perovskite from the Ti-bearing minerals because most titanium in the earth exists in the form of oxides. According to our experiments, a series of Ti-based perovskite could be fabricated by this method at low cost, such as $\mathrm{PbTiO}_{3}, \mathrm{BaTiO}_{3}$, $\mathrm{LaTiO}_{3}$, and so on.

No matter by Fe-Mn doping or light irradiation, the deNO ${ }_{x}$ activity of modified $\mathrm{CaTiO}_{3}$ mainly originates from the activation of NO. Hence, constructing photo-SCR catalysts from Ti-based perovskite should focus the principle issue on how to activate NO. Jonathan et al. ${ }^{27}$ proposed that the binding strength of NO on perovskite surface depends on the B-site $e_{g}$ filling, specifically, increasing with the decrease in $e_{g}$ 
filling in the range from 1 to 0.5 . According to our results, NO adsorption rises as the $e_{g}$ filling increases from 0 of $\mathrm{CaTiO}_{3}$ to 0.06 of $\mathrm{Ca}(\mathrm{Ti}, \mathrm{Mn}) \mathrm{O}_{3}$, indicating a volcano shape of $\mathrm{NO}$ adsorption as a function of $e_{g}$ filling in the range from 0 to 1 . The results also suggest that doping Ti-based perovskite with metal ions of $\mathrm{e}_{\mathrm{g}}$ filling greater than 0 , such as $\mathrm{Co}^{3+}$, and $\mathrm{Ni}^{3+}$, could augment $\mathrm{NO}$ adsorption. Furthermore, doping $\mathrm{CaTiO}_{3}$ simplifies the regulation of electronic structure on the optical property so that more attention could be put into how to activate NO. This strategy also extends the material range for photo$\mathrm{SCR}$ deNO${ }_{\mathrm{x}}$ to semiconductors of the wide bandgap.

It is widely accepted that $\mathrm{NH}_{2} \mathrm{NO}$ is a requisite in the cycle of standard $\mathrm{SCR}$, but the involvement of $\mathrm{NH}_{4} \mathrm{NO}_{2}$ is in dispute. Powerful evidence by the time-resolved spectroscopy from Marberger et al. ${ }^{10}$ showed that $\mathrm{NH}_{3}$ coordinated to Bronsted site $\left(\mathrm{B}_{\mathrm{NH} 3}\right)$ of $\mathrm{V}_{2} \mathrm{O}_{5}-\mathrm{WO}_{3}-\mathrm{TiO}_{2}$ does not participate in the catalytic cycle. $\mathrm{NH}_{3}$ binding to Lewis sites $\left(\mathrm{L}_{\mathrm{NH}}\right)$ could react with gaseous $\mathrm{NO}$ to form $\mathrm{NH}_{2} \mathrm{NO}$, generating a Bronsted acid site. However, if $\mathrm{L}_{\mathrm{NH} 3}$ could combine with this as-obtained Bronsted site, a new $\mathrm{B}_{\mathrm{NH} 3}$ would be produced. This $\mathrm{B}_{\mathrm{NH} 3}$ could be consumed by forming $\mathrm{NH}_{4} \mathrm{NO}_{2}$ so that the total amount of $\mathrm{B}_{\mathrm{NH} 3}$ remains constant, also explaining the results of Fig. 1 in ref 10. Therefore, the reaction mechanisms involving both $\mathrm{NH}_{2} \mathrm{NO}$ and $\mathrm{NH}_{4} \mathrm{NO}_{2}$ are also supported by Marberger's results.

A lot of enlightening studies ${ }^{12,13,43,44}$ reported that catalysts composed of different metal oxides are always superior to single metal oxide in terms of SCR performance. Most of the authors believed that the redox cycle between multivalent metal ions promotes $\mathrm{NO}$-to- $\mathrm{NO}_{2}$ oxidation, triggering the fast $\mathrm{SCR}$ reaction. Our results demonstrate that Fe-Mn doping of $\mathrm{CaTiO}_{3}$ acts on the standard SCR by shortening the reaction pathway, providing new insights into the synergistic effect between multivalent metal ions.

Emphasizing the synergistic effect between $\mathrm{Fe}$ and $\mathrm{Mn}$ does not mean that $\mathrm{Ti}$ is dispensible in this system. Instead, $\mathrm{Ti}$ of $\mathrm{Ca}(\mathrm{Ti}, \mathrm{Mn}, \mathrm{Fe}) \mathrm{O}_{3}$ has two momentous effects in the SCR process. First, the $\mathrm{Ti}_{5 \mathrm{c}}$ site selectively adsorbs $\mathrm{NH}_{3}$, initiating the catalytic cycle by reacting with chemisorbed $\mathrm{NO}$ on the $\mathrm{Mn}_{5 \mathrm{c}}$ site. The cooperation between $\mathrm{Ti}$ and $\mathrm{Mn}$ boosts the formation of $\mathrm{NH}_{2} \mathrm{NO}$, and is more efficient than that between two $\mathrm{Mn}$ sites since the high adsorption strength of $\mathrm{NO}$ on the $\mathrm{Mn}_{5 \mathrm{c}}$ site, to some extent, inhibits $\mathrm{NH}_{3}$ adsorption along with $\mathrm{NH}_{2} \mathrm{NO}$ formation. Second, Ti 3d orbitals are the main components of the valence band, dictating the optical property of perovskite. Owing to the unique function of $\mathrm{Ti}_{1} \mathrm{CaTiO}_{3}$ is a suitable framework to construct efficient catalytic units for photo-SCR deNO ${ }_{x}$.

$\mathrm{NH}_{3}$-SCR deNO ${ }_{x}$ involves three feeding gases, namely $\mathrm{NO}, \mathrm{NH}_{3}$, and $\mathrm{O}_{2}$. A single type of active site may lead to excessive coverage of the catalyst surface by specific gas molecules, thus lowering the reaction efficiency. Compared with modulating gas adsorption strength, constructing disparate sites to selectively activate gas molecules could be a more feasible alternative to heighten the SCR reaction rate.

\section{Methods}


Materials. The perovskite-based catalyst was directly extracted from Ti-bearing blast furnace slag (Tislag), which is a kind of metallurgical solid waste. More details about Ti-slag could be acquired in the supporting material. The Ti-slag was provided by Pangang Group Co., Ltd., China, and its chemical analysis is shown in Table 1. The slag was crushed, ground and sieved through a 200-mesh sieve before use. Unless otherwise specified, all of the rest reagents used in this study were of analytical grade and provided by Sinopharm Chemical Reagent Co., Ltd., China.

Catalyst preparation. To obtain the target perovskite from Ti-slag, a process involving mineral phase reconstruction followed by acid leaching was adopted. To be specific, a powder mixture composed of $100.0 \mathrm{~g}$ of Ti-slag, $23.0 \mathrm{~g}$ of $\mathrm{NaOH}, 10.0 \mathrm{~g}$ of $\mathrm{MnO}_{2}, 5.0 \mathrm{~g}$ of $\mathrm{Fe}_{2} \mathrm{O}_{3}$, and $5.0 \mathrm{~g}$ of $\mathrm{CeO}_{2}$ was placed in the $\mathrm{MgO}$ crucible and roasted at $1400^{\circ} \mathrm{C}$ for one hour. As the sintered sample was cooled to room temperature, it was crushed and ground into fine particles for acid leaching and characterization.

$15.0 \mathrm{~g}$ of the sintered sample power was placed in a glass beaker of $500 \mathrm{~mL}$, and then $225 \mathrm{~mL}$ of $8 \%$ hydrochloric acid was added into the beaker. The mixture was stirred with a Teflon agitator at $25^{\circ} \mathrm{C}$ for 60 min. In this way, almost all the aluminosilicates were dissolved and transferred into the solution. After the slurry was filtered, the solid residue was dried at $105^{\circ} \mathrm{C}$ for four hours for further analysis. The asobtained sample was denoted as $5 \mathrm{Ce} 5 \mathrm{Fe} 10 \mathrm{Mn}$, in which the number represents the mass ratio of the following oxide to Ti-slag. Likewise, the label ' $10 \mathrm{Mn}^{\prime}$ meant that the mass ratio of $\mathrm{MnO}_{2}$ to Ti-slag in the powder mixture was $10 \%$, and neither $\mathrm{CeO}_{2}$ nor $\mathrm{Fe}_{2} \mathrm{O}_{3}$ was incorporated into the mixture.

Catalyst characterization. X-ray diffraction (XRD) patterns were collected by the Rigaku X-ray

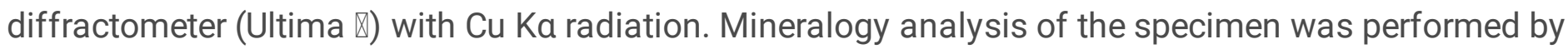
field emission scanning electron microscopy (SEM, JSM-6490LV) equipped with an Oxford energy dispersive X-ray spectroscope (EDS). Morphology analysis was carried out by scanning transmission electron microscopy in high-angle annular dark field (HAADF-STEM, FEI TalosF200x). The high-resolution mapping of elements was implemented by Super-X EDS.

Fe and Mn K-edge EXAFS measurements were carried out at the BL01B1 beamline at Spring-8 of the Japan Synchrotron Radiation Research Institute (JASRI). Ce $\mathrm{L}_{\square}$-edge EXAFS measurement was collected at the Beamline of TPS44A1 in National Synchrotron Radiation Research Center (NSRRC). All the measurements were performed at room temperature, and XAFS data were recorded in the fluorescent mode. The X-ray energy was calibrated using Fe and Mn foils, and the data analyses were performed utilizing Athena and Artemis in the Demeter software package.

X-ray photoelectron spectra (XPS) were recorded on a Thermo Scientific K-Alpha spectrometry using Al Ka irradiation. Raman spectra were obtained by the Renishaw Raman spectrophotometer. UV-vis diffuse reflectance spectra (DRS) of the specimens were recorded by a PerkinElmer Spectrometer (Lambda 950). The specific surface area of the specimen was measured by Brunauer-Emmett-Teller (BET) method. Both temperature-programmed reduction of $\mathrm{H}_{2}\left(\mathrm{H}_{2}\right.$-TPR) and desorption of $\mathrm{NH}_{3}\left(\mathrm{NH}_{3}\right.$-TPD) were implemented on a Huasi instrument (DAS-7000). 
In situ DRIFT experiments were performed on a Nicolet 6700 spectrometer in the wavenumber range of 2000 to $1000 \mathrm{~cm}^{-1}$ with $4 \mathrm{~cm}^{-1}$ resolution. In situ IR spectra were collected on a PerkinElmer spectrometer in the wavenumber range of 2000 to $800 \mathrm{~cm}^{-1}$ with $4 \mathrm{~cm}^{-1}$ resolution. The detailed procedures for in situ IR spectrum are as follows. First, the specimen was treated at $300{ }^{\circ} \mathrm{C}$ under $\mathrm{N}_{2}$ flow for $0.5 \mathrm{~h}$ to remove the species adsorbed on the specimen surface. Second, the specimen was regulated to the target temperature to obtain a background spectrum which should be subtracted from the specimen spectrum. Then, the specimen was exposed to a flow of $1000 \mathrm{ppm} \mathrm{NH}$ or $1000 \mathrm{ppm} \mathrm{NO}+3$ vol\% $\mathrm{O}_{2}$ for one hour, and the IR spectrum in the dark was recorded. Finally, the Xe lamp was turned on, and the IR spectrum under light irradiation was collected 15 min later.

Catalytic activity test. The SCR activity was tested in a fixed-bed reactor equipped with a Xenon lamp. The simulated gas consisted of $1000 \mathrm{ppm} \mathrm{NO}, 1000 \mathrm{ppm} \mathrm{NH}_{3}, 3$ vol\% $\mathrm{O}_{2}$, and a balance of $\mathrm{N}_{2}$, corresponding to a gas hourly space velocity (GHSV) of $72000 \mathrm{~h}^{-1}$. Both $\mathrm{NO}$ and $\mathrm{NO}_{2}$ were determined by a BUV150 flue gas analyzer, $\mathrm{NH}_{3}$ determined by a BLD200 analyzer, and $\mathrm{N}_{2} \mathrm{O}$ by a BGM250 analyzer. During the catalytic process, the reactor was cooled by circulating water to offset the temperature fluctuation caused by light irradiation. The $\mathrm{NO}$ conversion percentage and $\mathrm{N}_{2}$ selectivity were calculated by the following formula:

NO conversion $(\%)=\frac{[\mathrm{NO}]_{\text {in }}-[\mathrm{NO}]_{\text {out }}}{[\mathrm{NO}]_{\text {in }}} \times 100 \%(1)$

$\mathrm{N}_{2}$ selectivity $=\left(1-\frac{2\left[\mathrm{~N}_{2} \mathrm{O}\right]_{\text {out }}}{[\mathrm{NO}]_{\text {in }}+\left[\mathrm{NH}_{3}\right]_{\text {in }}-[\mathrm{NO}]_{\text {out }}-\left[\mathrm{NH}_{3}\right]_{\text {out }}}\right) \times 100 \%(2)$

Computational details. The structural relaxation and singlet energy point energy calculations were performed using the density functional theory (DFT) method as implemented in Vienna Ab initio Simulation Package (VASP) ${ }^{45,46}$. The generalized gradient approximation (GGA) in the form of PerdewBurke-Ernzerhof (PBE) functional was used to evaluate the exchange-correlation potential ${ }^{47}$. The projectaugmented wave approach was employed to represent the core-electron interaction. The atomic orbitals treated as valence states were as follows: $3 s 3 p 4 s$ of $\mathrm{Ca}, 3 d 4 s$ of $\mathrm{Ti}, 3 p 3 d 4 s$ of $\mathrm{Mn}, 3 p 3 d 4 s$ of $\mathrm{Fe}$, and $2 s 2 p$ of 0 . Hubbard corrections with $\mathrm{U}_{\text {eff }}=3.9 \mathrm{eV}$ and $5.3 \mathrm{eV}$ were applied to describe the $3 \mathrm{~d}$-orbitals of $\mathrm{Fe}$ and $\mathrm{Mn}$ atoms, respectively.

The lattice constant of relaxed bulk $\mathrm{CaTiO}_{3}$ was $5.36 \times 5.46 \times 7.62 \AA$ in reasonable agreement with the experimental value of $5.38 \times 5.44 \times 7.64 \AA(\mathrm{PDF} 078-1013)^{48}$. A periodic $\mathrm{CaTiO}_{3}(001)$ slab separated by a vacuum layer of $15 \AA$ was built from this lattice. In total, there are 80 atoms in each slab, containing 16 $\mathrm{Ca}, 14 \mathrm{Ti}, 1 \mathrm{Mn}, 1 \mathrm{Fe}$, and $48 \mathrm{O}$. The self-consistent field method with the tolerance of $1.0 \times 10^{-6} \mathrm{eV} / \mathrm{atom}$ and the plane wave basis sets with an energy cutoff of $500 \mathrm{eV}$ were adopted. The structural optimization was relaxed until the Hellman-Feynman force on each ion was less than $0.02 \mathrm{eV} / \AA$.

Adsorption energies of gas molecules, $\mathrm{E}_{\mathrm{ads}}$, in this paper were calculated as the following equation: 


$$
\mathrm{E}_{\mathrm{ads}}=\mathrm{E}_{\text {slab+gas }}-\mathrm{E}_{\text {slab }} \mathrm{E}_{\text {gas }}
$$

where $E_{\text {slag+gas }}$ is the total energy of the perovskite slab with a gas molecule bound to it, $E_{\text {slab }}$ is the total energy of the clean $\mathrm{CaTiO}_{3}$ slab, and $\mathrm{E}_{\text {gas }}$ is the total energy of the gas molecules.

\section{Declarations}

\section{Acknowledgments}

This work was supported by the National Natural Science Foundation of China [grant numbers 51804005, U1660110].

\section{References}

1. Teramura, K., Tanaka, T., Yamazoe, S., Arakaki, K. \& Funabiki, T. Kinetic study of photo-SCR with $\mathrm{NH}_{3}$ over $\mathrm{TiO}_{2}$. Appl. Catal. B-Environ. 53, 29-36, doi:https://doi.org/10.1016/j.apcatb.2004.05.005 (2004).

2. Tanaka, T., Teramura, K. \& Funabiki, T. Photoassisted selective catalytic reduction of NO with ammonia in the presence of oxygen at low temperature. Phys. Chem. Chem. Phys. 2, 2681-2682, doi:10.1039/B003264F (2000).

3. Zhang, $\mathrm{H}$. et al. Development of $\mathrm{La}_{1}-\mathrm{x} \mathrm{Ce}_{\mathrm{x}} \mathrm{FeO}_{3} /$ attapulgite nanocomposites for photocatalytic reduction of NO at low temperature. J Mater Sci-Mater. El. 28, 9371-9377, doi:10.1007/s10854-0176677-0 (2017).

4. Yamamoto, A., Teramura, K., Hosokawa, S., Shishido, T. \& Tanaka, T. Visible-Light-Assisted Selective Catalytic Reduction of Nitric Oxide with Ammonia over Dye-Modified Titania Photocatalysts. ChemCatChem 7, 1818-1825, doi:https://doi.org/10.1002/cctc.201500207 (2015).

5. Li, X. et al. Rational construction of direct Z-scheme doped perovskite/palygorskite nanocatalyst for photo-SCR removal of NO: Insight into the effect of Ce incorporation. J. Catal. 369, 190-200, doi:https://doi.org/10.1016/j.jcat.2018.11.009 (2019).

6. Yamamoto, A. et al. Visible-light-assisted selective catalytic reduction of $\mathrm{NO}$ with $\mathrm{NH}_{3}$ on porphyrin derivative-modified $\mathrm{TiO}_{2}$ photocatalysts. Catal. Sci. Technol. 5, 556-561, doi:10.1039/C4CY00598H (2015).

7. He, G. et al. Polymeric vanadyl species determine the low-temperature activity of V-based catalysts for the SCR of $\mathrm{NO}_{x}$ with $\mathrm{NH}_{3}$. Sci. Adv. 4 (2018).

8. Han, L. et al. Selective Catalytic Reduction of $\mathrm{NO}_{x}$ with $\mathrm{NH}_{3}$ by Using Novel Catalysts: State of the Art and Future Prospects. Chem. Rev. 119, 10916-10976 (2019). 
9. Arnarson, L., Falsig, H., Rasmussen, S. B., Lauritsen, J. V. \& Moses, P. G. A complete reaction mechanism for standard and fast selective catalytic reduction of nitrogen oxides on low coverage

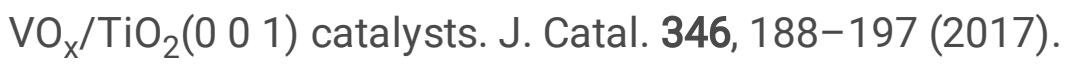

10. Marberger, A., Ferri, D., Elsener, M. \& Kröcher, O. The Significance of Lewis Acid Sites for the Selective Catalytic Reduction of Nitric Oxide on Vanadium-Based Catalysts. Angew. Chem. Int. Edit. 55, 11989-11994, doi:https://doi.org/10.1002/anie.201605397 (2016).

11. Paolucci, C. et al. Isolation of the Copper Redox Steps in the Standard Selective Catalytic Reduction on Cu-SSZ-13. Angew. Chem. Int. Edit. 53, 11828-11833, doi:https://doi.org/10.1002/anie.201407030 (2014).

12. Vuong, T. H. et al. Efficient $\mathrm{VO}_{\mathrm{x}} / \mathrm{Ce}_{1-\mathrm{x}} \mathrm{Ti}_{\mathrm{x}} \mathrm{O}_{2}$ Catalysts for Low-Temperature $\mathrm{NH}_{3}$-SCR: Reaction Mechanism and Active Sites Assessed by in Situ/Operando Spectroscopy. Angew. Chem. Int. Edit. 7, 1693-1705, doi:10.1021/acscatal.6b03223 (2017).

13. Zhu, M., Lai, J.-K., Tumuluri, U., Wu, Z. \& Wachs, I. E. Nature of Active Sites and Surface Intermediates during SCR of $\mathrm{NO}$ with $\mathrm{NH}_{3}$ by Supported $\mathrm{V}_{2} \mathrm{O}_{5}-\mathrm{WO}_{3} / \mathrm{TiO}_{2}$ Catalysts. J. Am. Chem. Soc. 139, 15624-15627, doi:10.1021/jacs.7b09646 (2017).

14. Zhang, Q. et al. Perovskite $\mathrm{LaFeO}_{3}-\mathrm{SrTiO}_{3}$ composite for synergistically enhanced $\mathrm{NO}$ removal under visible light excitation. Appl. Catal. B-Environ. 204, 346-357, doi:10.1016/j.apcatb.2016.11.052 (2017).

15. Li, X. et al. Full spectrum driven SCR removal of $\mathrm{NO}$ over hierarchical $\mathrm{CeVO}_{4} /$ attapulgite nanocomposite with high resistance to $\mathrm{SO}_{2}$ and $\mathrm{H}_{2} \mathrm{O}$. J. Hazard. Mater. 386, doi:10.1016/j.jhazmat.2019.121977 (2020).

16. $\mathrm{Li}, \mathrm{X}$. et al. Nanocomposite $\mathrm{LaFe}_{1-\mathrm{x}} \mathrm{Ni}_{\mathrm{x}} \mathrm{O}_{3} /$ Palygorskite catalyst for photo-assisted reduction of $\mathrm{NO}_{\mathrm{x}}$ : Effect of Ni doping. Appl. Catai. B-Environ. 231, 92-100, doi:https://doi.org/10.1016/j.apcatb.2018.03.008 (2018).

17. Cheng, G. et al. Visible-light-driven deep oxidation of $\mathrm{NO}$ over Fe doped $\mathrm{TiO}_{2}$ catalyst: Synergic effect of Fe and oxygen vacancies. Appl. Catal. B-Environ. 277, 119196, doi:https://doi.org/10.1016/j.apcatb.2020.119196 (2020).

18. Hong, W. T. et al. Toward the rational design of non-precious transition metal oxides for oxygen electrocatalysis. Energy Environ. Sci. 8, 1404-1427, doi:10.1039/C4EE03869J (2015).

19. Huang, H. et al. Photothermal-assisted triphase photocatalysis over a multifunctional bilayer paper. Angew. Chem. Int. Edit. 60, doi:https://doi.org/10.1002/anie.202110336 (2021).

20. Sun, Y., Han, L. \& Strasser, P. A comparative perspective of electrochemical and photochemical approaches for catalytic $\mathrm{H}_{2} \mathrm{O}_{2}$ production. Chem. Soc. Rev. 49, 6605-6631, doi:10.1039/DOCS00458H (2020).

21. Weng, B. et al. Simple descriptor derived from symbolic regression accelerating the discovery of new perovskite catalysts. Nat. Commun. 11, doi:10.1038/s41467-020-17263-9 (2020). 
22. Shen, T.-H. et al. Oxygen Evolution Reaction in $\mathrm{Ba}_{0.5} \mathrm{Sr}_{0.5} \mathrm{Co}_{0.8} \mathrm{Fe}_{0.2} \mathrm{O}_{3}$-delta Aided by Intrinsic $\mathrm{Co} / \mathrm{Fe}$ Spinel-Like Surface. J. Am. Chem. Soc. 142, 15876-15883, doi:10.1021/jacs.0c06268 (2020).

23. Zhang, Z. et al. Conversion of $\mathrm{CaTi}_{1-x} \mathrm{Mn}_{\mathrm{x}} \mathrm{O}_{3-\delta}$-Based Photocatalyst for Photocatalytic Reduction of NO via Structure-Reforming of Ti-Bearing Blast Furnace Slag. ACS Sustain. Chem. Eng. 7, 1029910309, doi:https://doi.org/10.1021/acssuschemeng.9b00097 (2019).

24. $\mathrm{Mu}$, J. et al. Inductive Effect Boosting Catalytic Performance of Advanced $\mathrm{Fe}_{1-x} \mathrm{~V}_{\mathrm{x}} \mathrm{O}_{\delta}$ Catalysts in Low-Temperature $\mathrm{NH}_{3}$ Selective Catalytic Reduction: Insight into the Structure, Interaction, and Mechanisms. ACS Catal. 8, 6760-6774, doi:10.1021/acscatal.8b01196 (2018).

25. Wang, K., Fung, V., Wu, Z. \& Jiang, D.-e. Stable Surface Terminations of a Perovskite Oxyhydride from First Principles. J. Phys. Chem. C, doi:10.1021/acs.jpcc.0c03956 (2020).

26. Wang, H., Wang, G., Wei, X. \& Cui, J. First-principles study of $\mathrm{CaTiO}_{3}$ oxygen-vacancies (001) surface. Physica B 407, 3970-3974, doi:https://doi.org/10.1016/j.physb.2012.06.022 (2012).

27. Hwang, J. et al. Perovskites in catalysis and electrocatalysis. Science $358,751-756$, doi:10.1126/science.aam7092 (2017).

28. Peng, Y., Li, K. \& Li, J. Identification of the active sites on $\mathrm{CeO}_{2}-\mathrm{WO}_{3}$ catalysts for $\mathrm{SCR}$ of $\mathrm{NO}_{\mathrm{x}}$ with $\mathrm{NH}_{3}$ : An in situ IR and Raman spectroscopy study. Appl. Catal. B-Environ. 140-141, 483-492, doi:https://doi.org/10.1016/j.apcatb.2013.04.043 (2013).

29. Chen, Z. et al. $\mathrm{Cr}-\mathrm{MnO}_{\mathrm{x}}$ mixed-oxide catalysts for selective catalytic reduction of $\mathrm{NO}_{x}$ with $\mathrm{NH}_{3}$ at low temperature. J. Catal. 276, 56-65, doi:https://doi.org/10.1016/j.jcat.2010.08.016 (2010).

30. Chang, $\mathrm{H}$. et al. Improvement of Activity and $\mathrm{SO}_{2}$ Tolerance of Sn-Modified $\mathrm{MnO}_{\mathrm{x}}-\mathrm{CeO}_{2}$ Catalysts for $\mathrm{NH}_{3}$-SCR at Low Temperatures. Environ. Sci. Technol. 47, 5294-5301, doi:10.1021/es304732h (2013).

31. Salazar, M., Becker, R. \& Grunert, W. Hybrid catalysts-an innovative route to improve catalyst performance in the selective catalytic reduction of $\mathrm{NO}$ by $\mathrm{NH}_{3}$. Appl. Catal. B-Environ. 165, 316-327, doi:10.1016/j.apcatb.2014.10.018 (2015).

32. Janssens, T. V. W. et al. A Consistent Reaction Scheme for the Selective Catalytic Reduction of Nitrogen Oxides with Ammonia. ACS Catal. 5, 2832-2845, doi:10.1021/cs501673g (2015).

33. Liu, $\mathrm{H}$. et al. Improved activity and significant $\mathrm{SO}_{2}$ tolerance of samarium modified $\mathrm{CeO}_{2}-\mathrm{TiO}_{2}$ catalyst for $\mathrm{NO}$ selective catalytic reduction with NH3. Appl. Catal. B-Environ. 244, 671-683, doi:10.1016/j.apcatb.2018.12.001 (2019).

34. Kim, N.-l. et al. B-site doping effects of $\mathrm{NdBa}_{0.75} \mathrm{Ca}_{0.25} \mathrm{Co}_{2} \mathrm{O}_{5+\delta}$ double perovskite catalysts for oxygen evolution and reduction reactions. J. Mater. Chem. A 6, 17807-17818, doi:10.1039/C8TA06236F (2018).

35. Wu, Q. \& Van de Krol, R. Selective Photoreduction of Nitric Oxide to Nitrogen by Nanostructured $\mathrm{TiO}_{2}$ Photocatalysts: Role of Oxygen Vacancies and Iron Dopant. J. Am. Chem. Soc. 134, 9369-9375, doi:10.1021/ja302246b (2012). 
36. Liu, Y. et al. DRIFT Studies on the Selectivity Promotion Mechanism of Ca-Modified Ce-Mn/ $/ \mathrm{TiO}_{2}$ Catalysts for Low-Temperature NO Reduction with NH3. J. Phys. Chem. C 116, 16582-16592, doi:10.1021/jp304390e (2012).

37. Inomata, Y. et al. Bulk tungsten-substituted vanadium oxide for low-temperature $\mathrm{NO}_{\mathrm{x}}$ removal in the presence of water. Nat. Commun. 12, doi:10.1038/s41467-020-20867-w (2021).

38. Liu, F., Shan, W., Lian, Z., Liu, J. \& He, H. The smart surface modification of $\mathrm{Fe}_{2} \mathrm{O}_{3}$ by $\mathrm{WO}_{\mathrm{x}}$ for significantly promoting the selective catalytic reduction of $\mathrm{NO}_{x}$ with $\mathrm{NH}_{3}$. Appl. Catal. B-Environ. 230, 165-176, doi:https://doi.org/10.1016/j.apcatb.2018.02.052 (2018).

39. Busca, G., Lietti, L., Ramis, G. \& Berti, F. Chemical and mechanistic aspects of the selective catalytic reduction of $\mathrm{NO}_{\mathrm{x}}$ by ammonia over oxide catalysts: A review. Appl. Catal. B-Environ. 18, 1-36, doi:https://doi.org/10.1016/S0926-3373(98)00040-X (1998).

40. Adamowska, M., Krztoń, A., Najbar, M., Da Costa, P. \& Djéga-Mariadassou, G. DRIFT study of the interaction of $\mathrm{NO}$ and $\mathrm{O}_{2}$ with the surface of $\mathrm{Ce}_{0.62} \mathrm{Zr}_{0.38} \mathrm{O}_{2}$ as deNO $\mathrm{x}_{\mathrm{x}}$ catalyst. Catal. Today 137, 288-291, doi:https://doi.org/10.1016/j.cattod.2008.01.013 (2008).

41. Huang, X., Dong, F., Zhang, G., Guo, Y. \& Tang, Z. A strategy for constructing highly efficient yolk-shell Ce@Mn@TiO ${ }_{x}$ catalyst with dual active sites for low-temperature selective catalytic reduction of NO with NH3. Chem. Eng. J. 419, 129572, doi:https://doi.org/10.1016/j.cej.2021.129572 (2021).

42. Shi, $\mathrm{H}$. et al. Sol-gel Synthesis of $\mathrm{LaBO}_{3} /$ Attapulgite $(\mathrm{B}=\mathrm{Mn}, \mathrm{Fe}, \mathrm{Co}, \mathrm{Ni}) \mathrm{Nanocomposite}$ for $\mathrm{NH}_{3}-\mathrm{SCR}$ of NO at Low Temperature. J. Inorg. Organomet. P. 27, S166-S172, doi:10.1007/s10904-017-0683-9 (2017).

43. Liu, Z. et al. Fe-Doped $\mathrm{Mn}_{3} \mathrm{O}_{4}$ Spinel Nanoparticles with Highly Exposed Feoct-O-Mntet Sites for Efficient Selective Catalytic Reduction (SCR) of NO with Ammonia at Low Temperatures. ACS Catal. 10, 6803-6809, doi:10.1021/acscatal.0c01284 (2020).

44. Liu, C. et al. A comparative study of $\mathrm{MO}_{\mathrm{x}}(\mathrm{M}=\mathrm{Mn}$, $\mathrm{Co}$ and $\mathrm{Cu})$ modifications over $\mathrm{CePO}_{4}$ catalysts for selective catalytic reduction of $\mathrm{NO}$ with $\mathrm{NH}_{3}$. J. Hazard. Mater. 363, 439-446, doi:10.1016/j.jhazmat.2018.09.054 (2019).

45. Kresse, G. \& Furthmuller, J. Efficiency of ab-initio total energy calculations for metals and semiconductors using a plane-wave basis set. Comp. Mater. Sci. 6, 15-50, doi:https://doi.org/10.1016/0927-0256(96)00008-0 (1996).

46. Kresse, G. \& Hafner, J. Ab initio molecular-dynamics simulation of the liquid-metal-amorphoussemiconductor transition in germanium. Phys. Rev. B Condens. Matter. Mater. Phys. 49, 1425114269, doi:https://doi.org/10.1103/PhysRevB.49.14251 (1994).

47. Perdew, J. P., Burke, K. \& Ernzerhof, M. Generalized gradient approximation made simple. Phys. Rev. Lett. 77, 3865-3868, doi:https://doi.org/10.1103/PhysRevLett.77.3865 (1996).

48. Sasaki, S., Prewitt, C. T., Bass, J. D. \& Schulze, W. A. Orthorhombic perovskite $\mathrm{CaTiO}_{3}$ and $\mathrm{CdTiO}_{3}$ : structure and space group. Acta Crystallogr. C 43, 1668-1674, doi:doi:10.1107/S0108270187090620 (1987). 


\section{Figures}

a

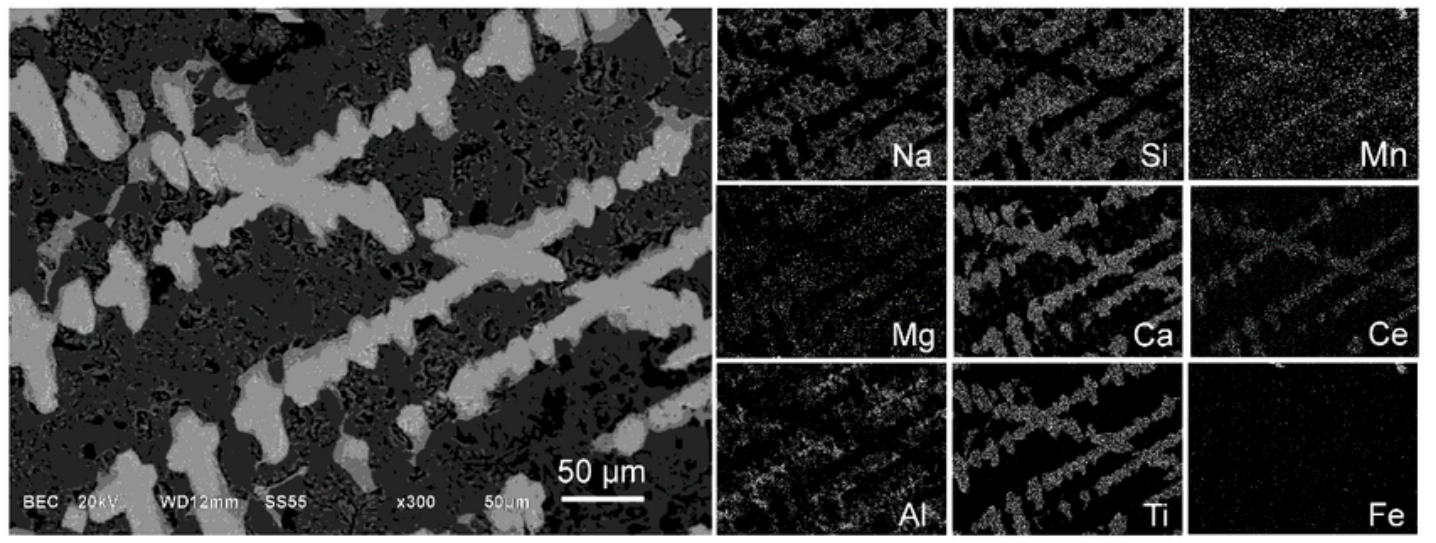

b

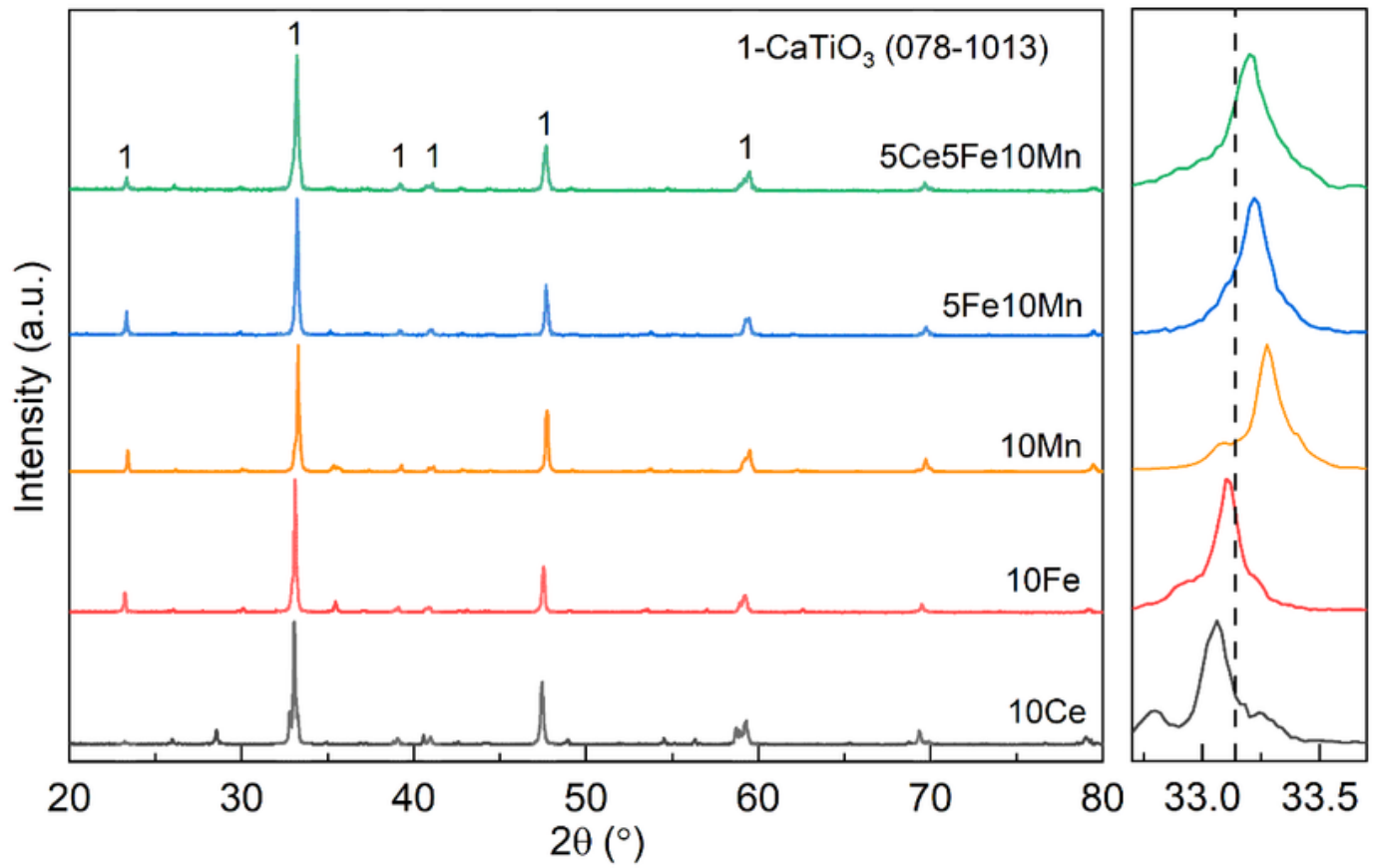

C
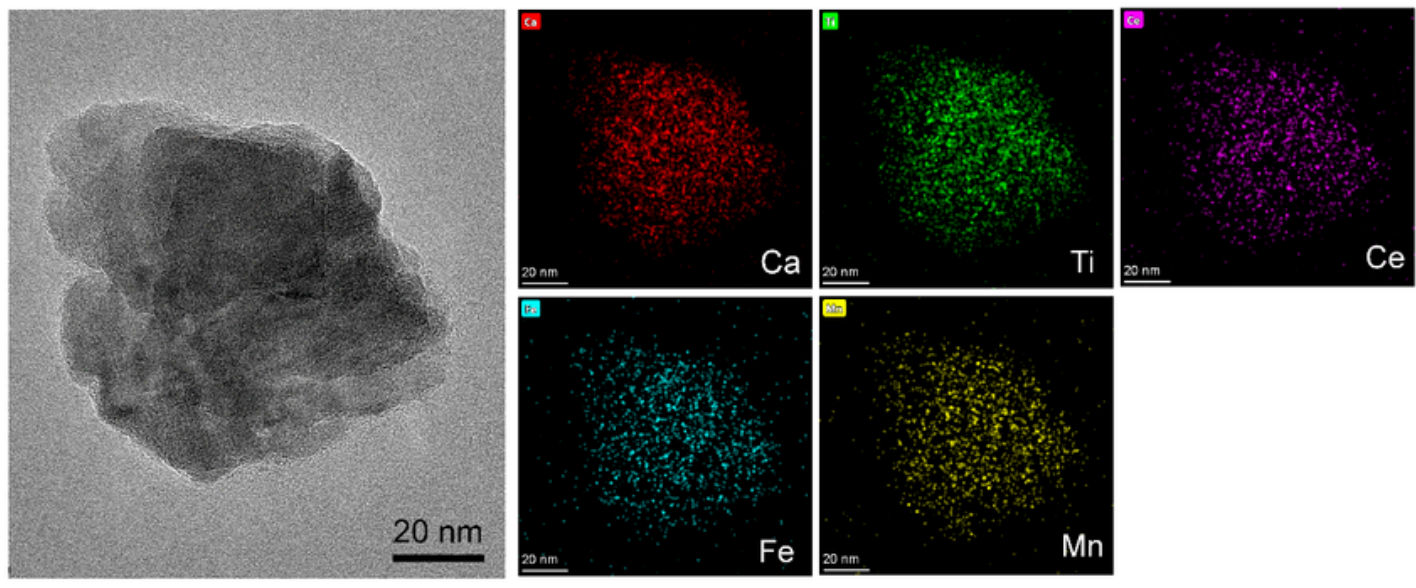

Figure 1

Phases and morphology of the roasted oxides and perovskite sample. a, Typical section morphology and element mapping of the composite oxides $\left(1400^{\circ} \mathrm{C}\right.$-roasted Ti-slag with $\mathrm{NaOH}, \mathrm{CeO}_{2}, \mathrm{Fe}_{2} \mathrm{O}_{3}$, and $\mathrm{MnO}_{2}$ ) obtained by SEM and EDS analysis. $\mathbf{b}$, XRD patterns of the perovskite samples. The right part is the high- 
resolution XRD patterns within $32.7^{\circ}$ to $33.7^{\circ}$. The dashed line denotes the position of the (112) peak from pure $\mathrm{CaTiO}_{3}$. c, HAADF-STEM image and EDS mapping of sample 5Ce5Fe10Mn.
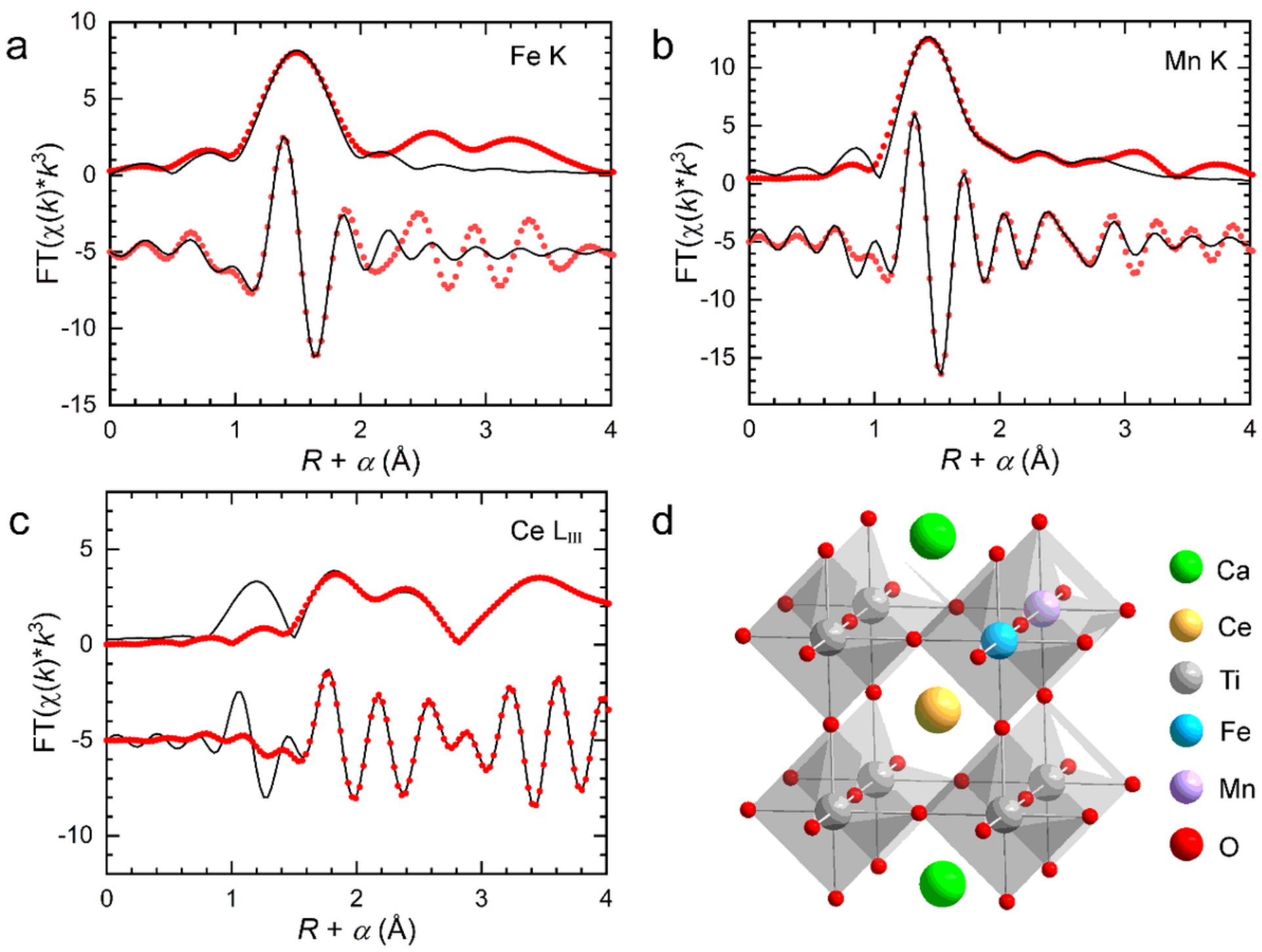

Figure 2

Crystal structure of the perovskite sample. a, Fe K-edge EXAFS (points) and curvefit (line) for $5 \mathrm{Ce} 5 \mathrm{Fe} 10 \mathrm{Mn}$, shown in R-space (FT magnitude and imaginary component); $\mathbf{b}, \mathrm{Mn}$ K-edge EXAFS (points) and curvefit (line) for 5Ce5Fe10Mn; c, Ce $\mathrm{L}_{\square}$-edge EXAFS (points) and curvefit (line) for 10Ce. All the data are $\mathrm{k}^{3}$-weighted and not phase-corrected. $\mathbf{d}$, Diagram of the crystal structure of $\mathrm{CaTiO}_{3}$ doped with $\mathrm{Ce}, \mathrm{Fe}$, and $\mathrm{Mn}$. 

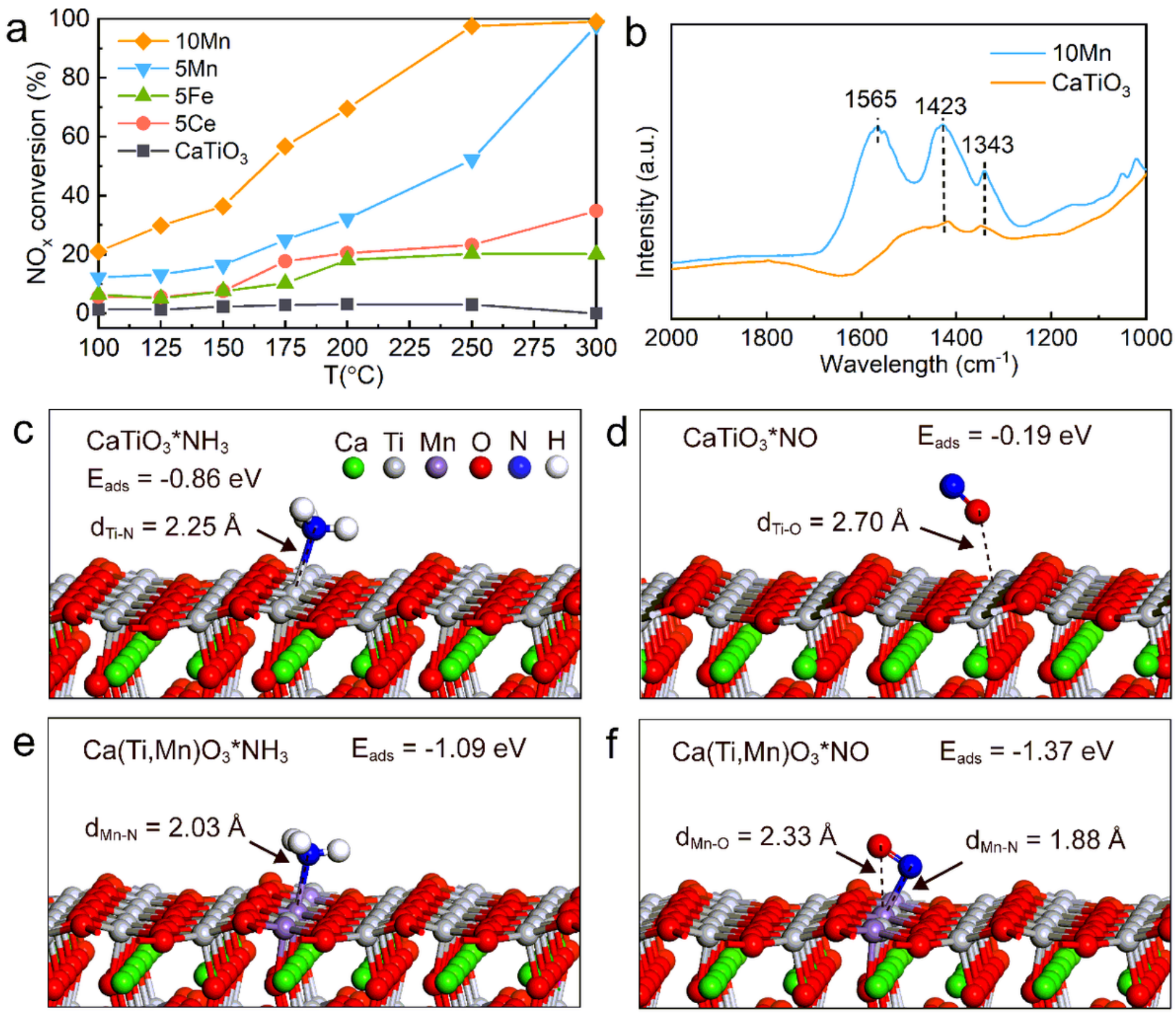

Figure 3

$\mathrm{NH}_{3}$-SCR activity of singleelement doped $\mathrm{CaTiO}_{3}$. a, Temperature-dependent $\mathrm{NO}_{\mathrm{x}}$ conversion over $\mathrm{CaTiO}_{3}$ doped with a single element in the dark. ( 1000 ppm NO, 1000 ppm NH 3,3 vol\% $\mathrm{O}_{2}$, GHSV $=72000 \mathrm{~h}^{-1}$ ). b, In situ DRIFT of $\mathrm{CaTiO}_{3}$ and $10 \mathrm{Mn}$ with $\mathrm{NO}+\mathrm{O}_{2}$ adsorbed at $25^{\circ} \mathrm{C}$ in the dark. The adsorption of $\mathrm{NH}_{3}(\mathbf{c})$ and $\mathrm{NO}$ (d) on the $\mathrm{TiO}_{2}-(001)$ termination of $\mathrm{CaTiO}_{3}$; the adsorption of $\mathrm{NH}_{3}(\mathbf{e})$ and $\mathrm{NO}(\mathbf{f})$ on the $\mathrm{TiO}_{2}-$ (001) termination of $\mathrm{Ca}(\mathrm{Ti}, \mathrm{Mn}) \mathrm{O}_{3}$. 
a

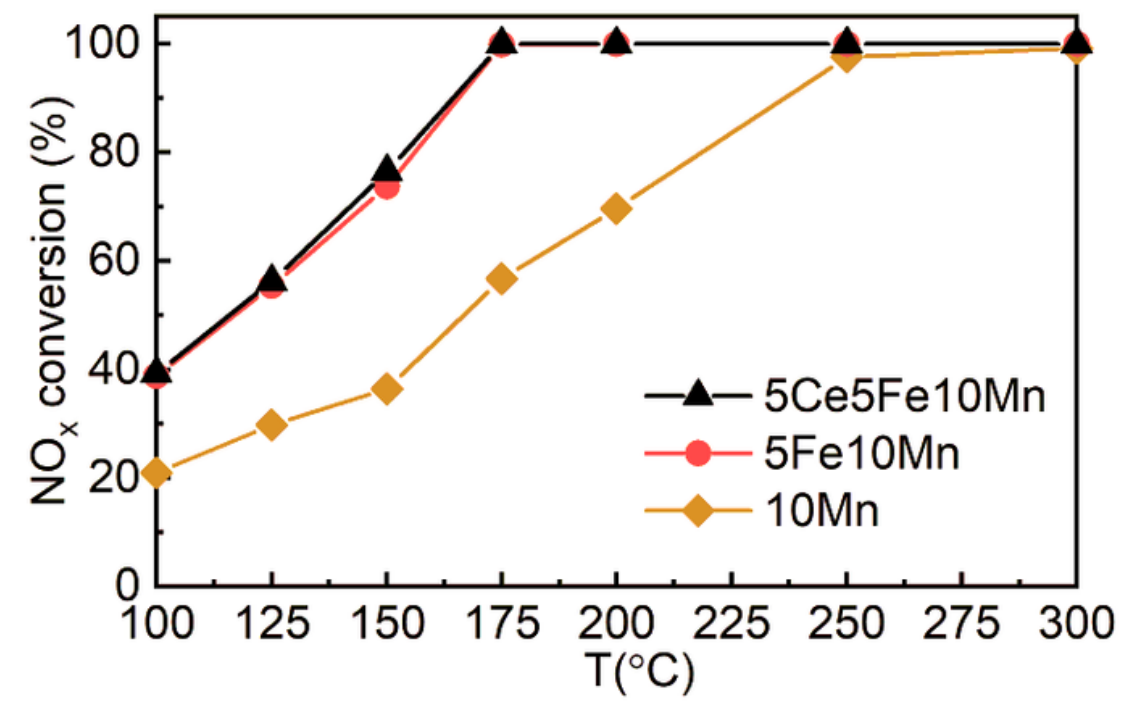

$b$

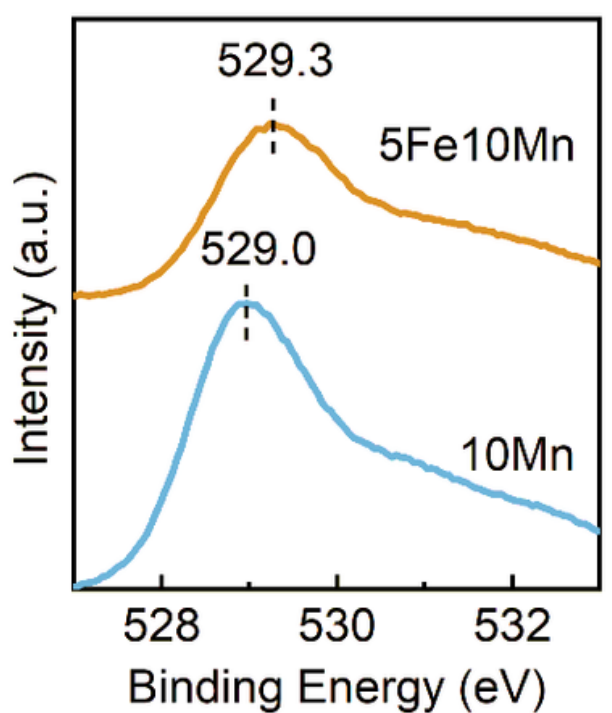

C

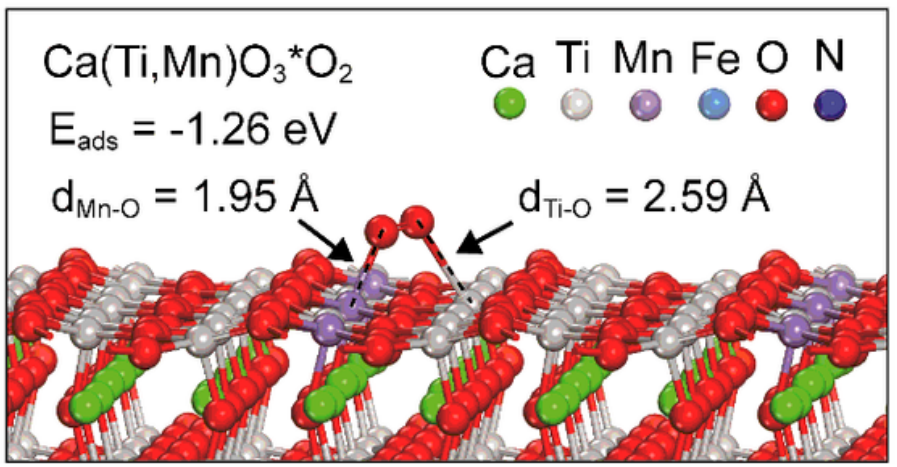

e

$\mathrm{Ca}(\mathrm{Ti}, \mathrm{Mn}, \mathrm{Fe}) \mathrm{O}_{3}{ }^{*} \mathrm{O}_{2} \quad \mathrm{E}_{\mathrm{ads}}=-1.12 \mathrm{eV}$

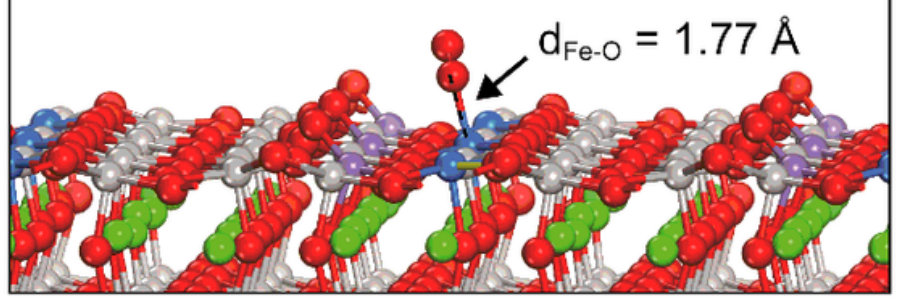

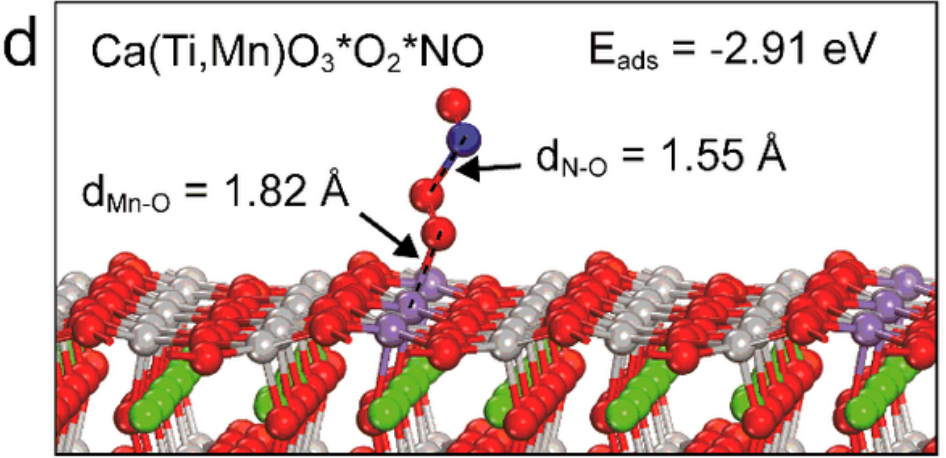

$f$

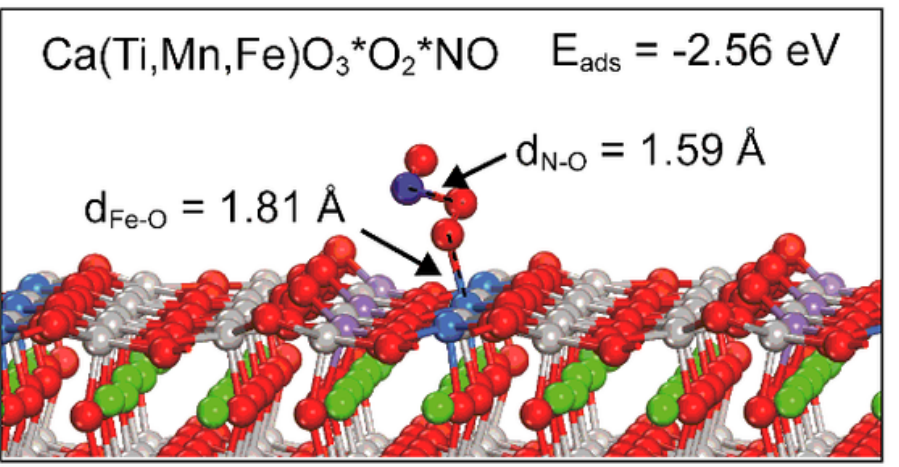

Figure 4

$\mathrm{NH}_{3}$-SCR activity of multielement doped $\mathrm{CaTiO}_{3}$. a, Temperature-dependent $\mathrm{NO}_{x}$ conversion over $\mathrm{CaTiO}_{3}$ doped with multiple elements in the dark. (1000 ppm NO, 1000 ppm NH $\mathrm{N}_{3}, 3$ vol\% $\mathrm{O}_{2}$, GHSV $=72000 \mathrm{~h}^{-1}$ ). b, XPS of 01 s from $10 \mathrm{Mn}$ and $5 \mathrm{Fe} 10 \mathrm{Mn}$. The adsorption of $\mathrm{O}_{2}(\mathbf{c})$ and $\mathrm{O}_{2}+\mathrm{NO}(\mathbf{d})$ on the $(\mathrm{Ti}, \mathrm{Mn}) \mathrm{O}_{2}-(001)$ termination of $\mathrm{Ca}(\mathrm{Ti}, \mathrm{Mn}) \mathrm{O}_{3}$; the adsorption of $\mathrm{O}_{2}(\mathbf{e})$ and $\mathrm{O}_{2}+\mathrm{NO}(\mathbf{f})$ on the $(\mathrm{Ti}, \mathrm{Mn}, \mathrm{Fe}) \mathrm{O}_{2}-(001)$ termination of $\mathrm{Ca}(\mathrm{Ti}, \mathrm{Mn}, \mathrm{Fe}) \mathrm{O}_{3}$. 


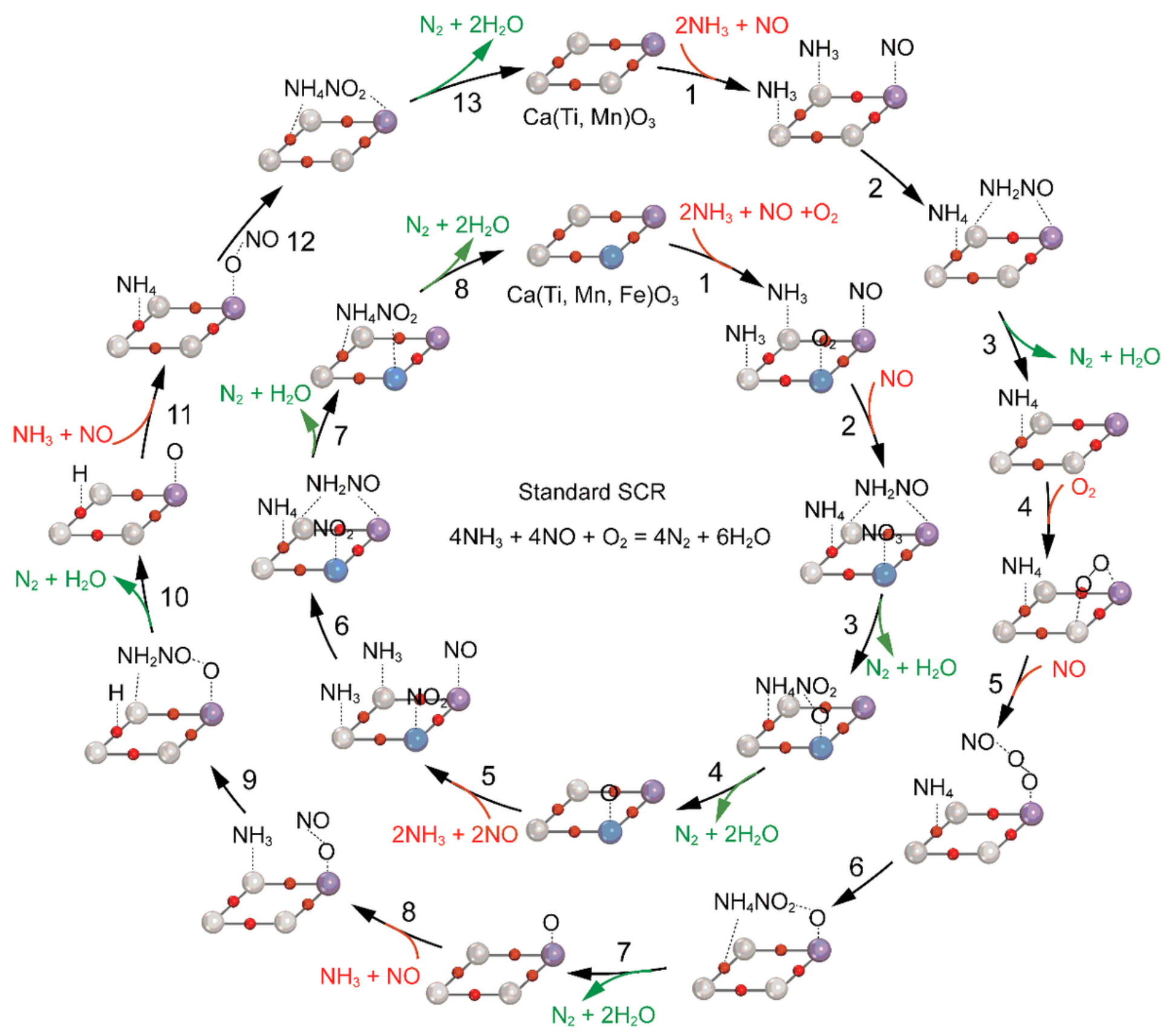

Figure 5

Proposed reaction pathways of Standard SCR over the perovskite. The reaction pathways of the regeneration of active sites from $\mathrm{Ca}(\mathrm{Ti}, \mathrm{Mn}) \mathrm{O}_{3}$ (the outer ring) and $\mathrm{Ca}(\mathrm{Ti}, \mathrm{Mn}, \mathrm{Fe}) \mathrm{O}_{3}$ (the inner ring) partially based on the DFT calculations. 

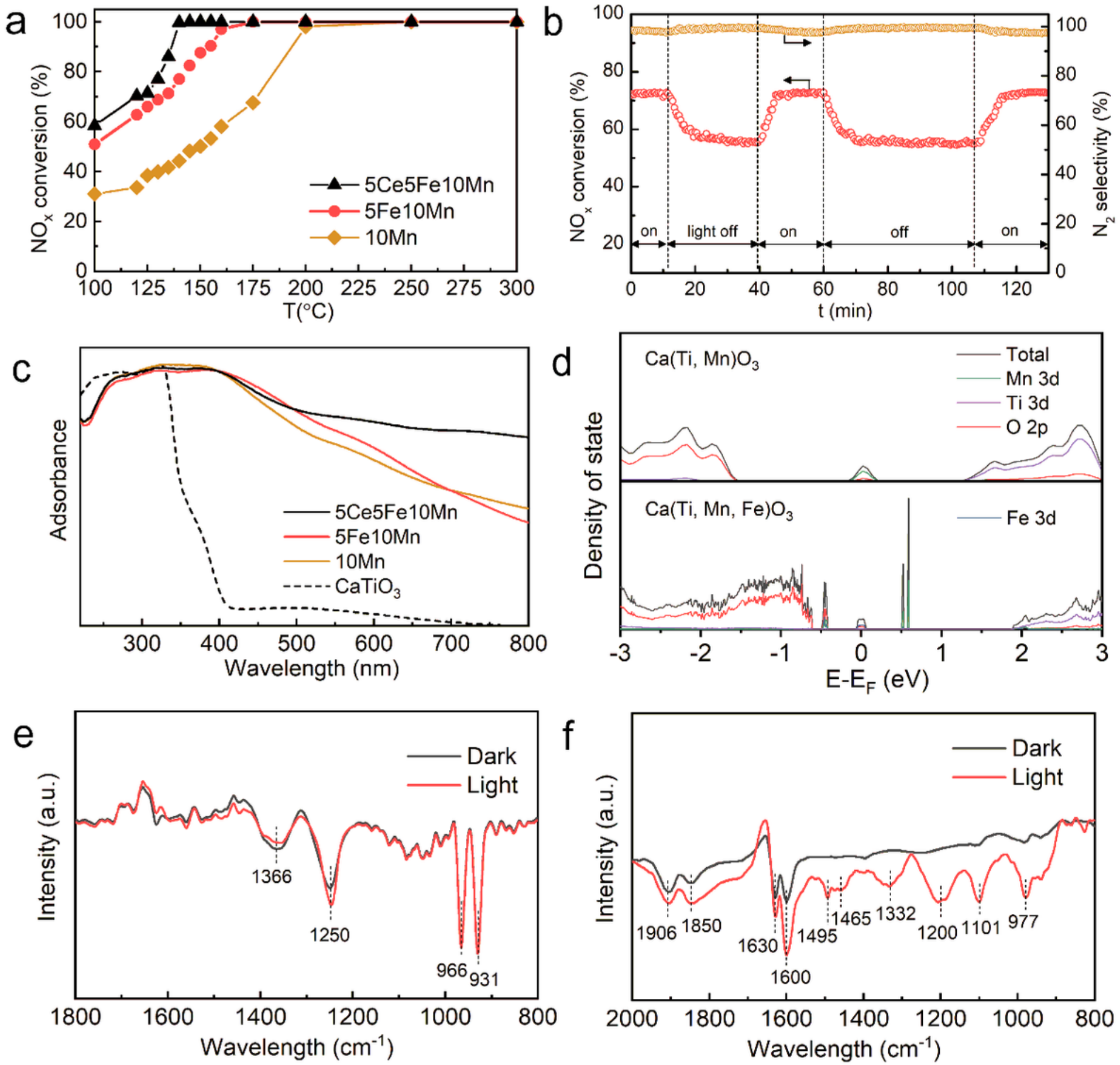

Figure 6

Photo-SCR activity of doped $\mathrm{CaTiO}_{3}$. a, Temperature-dependent $\mathrm{NO}_{x}$ conversion over $10 \mathrm{Mn}, 5 \mathrm{Fe} 10 \mathrm{Mn}$, and $5 \mathrm{Ce} 5 \mathrm{Fe} 10 \mathrm{Mn}$ under visible light irradiation; b, Light on-off cycle tests over $5 \mathrm{Ce} 5 \mathrm{Fe} 10 \mathrm{Mn}$ at $125^{\circ} \mathrm{C}$. C, UV-vis absorption spectra of the perovskite. d, PDOS of $\mathrm{Ca}(\mathrm{Ti}, \mathrm{Mn}) \mathrm{O}_{3}$ and $\mathrm{Ca}(\mathrm{Ti}, \mathrm{Mn}, \mathrm{Fe}) \mathrm{O}_{3}$. e, in situ IR spectra of $5 \mathrm{Ce} 5 \mathrm{Fe} 10 \mathrm{Mn}$ with $\mathrm{NH}_{3}$ adsorbed in the dark and visible light at $125^{\circ} \mathrm{C}$; $\mathbf{f}$, in situ IR spectra of $5 \mathrm{Ce} 5 \mathrm{Fe} 10 \mathrm{Mn}$ with $\mathrm{NO}+\mathrm{O}_{2}$ adsorbed in the dark and visible at $125^{\circ} \mathrm{C}$.

\section{Supplementary Files}


This is a list of supplementary files associated with this preprint. Click to download.

- Supplementaryinformation.docx

- Video1.mp4

- Video2.mp4 